\title{
IMMUNOREACTIVE CORTISOL MEASUREMENT IN CANINE URINE AND ITS VALIDITY IN HYPERADRENOCORTICISM DIAGNOSIS
}

\author{
J. KOLEVSKÁ, M. SVOBODA \\ Small Animal Clinic, Faculty of Veterinary Medicine, University of Veterinary and Pharmaceutical Sciences \\ Brno, Czech Republic \\ Received February 29, 2000 \\ Accepted July 27, 2000
}

Abstract

Kolevská J., M. Svoboda: Immunoreactive Cortisol Measurement in Canine Urine and its Validity in Hyperadrenocorticism Diagnosis. Acta Vet. Brno 2000, 69: 217-223.

The aim of this study was to compare two methods of immunoreactive cortisol determination in urine and an assessment of the validity of urine cortisol/creatinine ratio (UCCR) in dogs. The UCCR was measured in three groups of dogs: (1) healthy dogs, (2) dogs with hyperadrenocorticism and (3) dogs suffering from other diseases presented with polyuria and polydipsia (PU/PD). All cortisol measurements in urine were performed using two methods: (1) fluorescence polarisation immunoassay (FPIA) with urine extraction and (2) radioimmunoassay (RIA) without urine extraction. Paired results of 30 cortisol measurements and 30 UCCR were compared using the Wilcoxon test. It was proved that the differences between the two methods (i.e., FPIA with urine extraction and RIA without urine extraction) were highly statistically significant $(p<0.01)$. While in the cortisol measurement using the FPIA with urine extraction the median of the UCCR amounted to $18.53 \times 10^{-6}$, in the RIA without urine extraction it was $37.83 \times 10^{-6}$. Values of the UCCR in individual canine groups were also compared with each other. The UCCR in dogs with hyperadrenocorticism was higher $(p<0.01)$ than in healthy dogs or dogs presented with the PU/PD signs. There were also found significant differences $(p<0.05)$ between the UCCR in healthy dogs and dogs presented with PU/PD signs. Both methods of immunoreactive cortisol determination in urine can be used for clinical diagnosis of hyperadrenocorticism, however, the above mentioned differences should be considered.

Hyperadrenocorticism, cortisol, creatinine, RIA, FPIA, urine extraction

Hyperadrenocorticism is one of the most frequent endocrinopathies in dogs. It is the result of chronic glucocorticoid excess in peripheral blood (Feld man 1996). There are two basic forms of the disease: spontaneous and iatrogenic ones.

Spontaneous hyperadrenocorticism is in $85 \%$ pituitary-dependent and in $15 \%$ of adrenocortical origin (Rijnberk 1996). The central hyperadrenocorticism results from ACTH hypersecretion which is caused by hyperplastic lesions of corticotrophic pituitary cells (McNicol et al. 1983). Peripheral hyperadrenocorticism is caused by adrenocortical adenomas or adenocarcinomas (Reusch and Feldman 1991; Kemppainen and Peters on 1994). Iatrogenic hyperadrenocorticism results from application of exogenous glucocorticoids (Kemppainen et al 1982; Moriello et al 1988; Moore et al 1992).

There are no differences in the clinical manifestation of individual forms of the disease (Orth 1995). It is a disease of middle-aged and older animals manifested by polyuria, polydipsia, polyphagia, lethargy, non-pruritic symmetrical alopecia, skin thinning, comedones, calcinosis cutis, and muscle weakness (Peterson 1984). The hematologic profile is characterised by neutrophilia, lymphopenia, eosinopenia, and monocytosis. The following changes are typical of the biochemical profile: marked ALP elevation, mild hyperglycaemia, hypercholesterolemia, hypernatremia, hypokalemia, hypothyroxinemia (Meijer et al 1978; Miller and Crapo 1994).

Dynamic functional tests are used for specific disease diagnosis. The aim of these tests is

Address for correspondence:

MVDr. Jana Kolevská

Klinic

University of Veterinary and Pharmaceutical Sciences

Palackého 1-3, 614 42 Brno, Czech Republic

Phone: +420 54156281

E-mail: kolevska@ fucz 
to measure the sensitivity of the hypothalamic-pituitary-adrenocortical axis (Feldman et al. 1996). Changes in the cortisol production within a given time interval (depending on the test used) following synthetic hormone administration (i.e., ACTH or dexamethasone in dependence on the test used) are evaluated. On the basis of changes in the cortisol production it is possible to distinguish healthy animals from those with hyperadrenocorticism as well as the central and peripheral forms of the disease (Feldman 1983; Norman et al 1999).

It is possible to measure cortisol levels either in the blood plasma, serum or urine. Most of the cortisol (over 90\%) in the blood circulation is bound to transcortin and to a lesser degree to albumins and testosterone-estradiol-binding globulins. Only less than $10 \%$ of the circulating cortisol is present as the free physiologically active form which is excreted in urine.

The most frequently used diagnostic tests for the hyperadrenocorticism are: ACTH stimulation test, low-dose dexamethasone test, and UCCR measurement. It is the high-dose dexamethasone suppression test that is used for the purpose of distinguishing the central and peripheral forms of the disease (Rijnberk 1996; Svoboda et al 1998).

Even though the above tests are highly sensitive and specific, all of them may yield false positive and false negative results.

It is the aim of this paper to compare values of the UCCR obtained using two methods for the immunoreactive cortisol measurement in urine: i.e., FPIA with urine extraction and RIA without urine extraction. The UCCR was studied in healthy dogs, dogs with hyperadrenocorticism and dogs having other diseases presented with polyuria and polydipsia.

\section{Materials and Methods}

Dogs were divided into three groups: (1) healthy dogs $(\mathrm{n}=10)$, (2) dogs with hyperadrenocorticism $(\mathrm{n}=10)$, (3) dogs having other diseases and presented with polyuria and polydipsia $(n=10)$. The group of healthy dogs contained individuals in which no clinical or laboratory (haematology, biochemistry and urinalysis) signs of any disease were present. The group of dogs with other diseases presented with polyuria and polydipsia contained mainly patients with diabetes mellitus without insulin resistance. Apart from diabetic patients, this group contained also patients with PU/PD because of other diseases. One such patient suffered from chronic active hepatitis and the other from psychogenic polydipsia. The third group contained individuals with typical clinical and laboratory signs of hyperadrenocorticism. A total number of 60 urine samples was analysed.

Dogs were sampled for urine at $07.00 \mathrm{~h}$, on two successive days, after taking them out for voiding at $23.00 \mathrm{~h}$. Urine from spontaneous micturition was collected. Samples from both days were equally divided and frozen at $-18^{\circ} \mathrm{C}$.

Immunoreactive cortisol levels in each sample were measured using two methods: (1) fluorescence polarisation immunoassay - FPIA (TDx system) with urine extraction (Abbott Comp., No 9116-60) and (2) radioimmunoassay - RIA without urine extraction (Immunotech Comp., No 1841). Dichlormethan was used for the urine extraction. In all, 120 urine cortisol measurements were performed. Creatinine levels were measured only once in each sample; i.e., a total of 60 measurements were made. The results obtained were used to compute the UCCR. The mean UCCR for each patient was then determined by making an average from both computed values.

No other dynamic diagnostic tests for the hyperadrenocorticism were performed.

Using the Wilcoxon test, we compared 30 paired values of urine cortisol and 30 paired $\mathrm{C} / \mathrm{C}$ ratios. We also compared values of the UCCR of healthy dogs, dogs with hyperadrenocorticism and dogs suffering from other diseases presented with PU/PD using the Mann-Whitney test.

The Kruskal-Wallis test and the Neményi test of multiple comparisons were employed for the purpose of determining whether there were differences in creatinine levels in urine of healthy dogs, dogs with hyperadrenocorticism and dogs suffering from other diseases presented with PU/PD.

\section{Results}

Comparison of FPIA with urine extraction and RIA without urine extraction methods

Comparing 30 paired values of urine cortisol measurements and 30 paired values of the UCCR, statistically highly significant differences $(p<0.01)$ were found between these two methods. While the median of the cortisol concentration in the cortisol measurement using 
the FPIA with urine extraction amounted to $104 \mathrm{nmol} / \mathrm{l}$, in the RIA without urine extraction measurement it was $188 \mathrm{nmol} / \mathrm{l}$. The median of the UCCR in the cortisol measurement using the FPIA with urine extraction and the RIA without urine extraction was equal to $18.53 \times$ $10^{-6}$ and $37.83 \times 10^{-6}$, respectively.

Table 1 and Fig 1

C/C RATIO

\begin{tabular}{|c|c|c|c|c|c|}
\hline \multicolumn{3}{|c|}{ FPIA method urine extraction } & \multicolumn{3}{c|}{ RIA method without urine extraction } \\
\hline Cushing-FPIA & Healthy-FPIA & PU/PD-FPIA & Cushing-RIA & Healthy-RIA & PU/PD-RIA \\
\hline 137.73 & 13.92 & 21.52 & 184.55 & 24.8 & 64.9 \\
\hline 265 & 5.9 & 7.95 & 407.86 & 9.41 & 58.85 \\
\hline 222.6 & 7.29 & 12.87 & 346 & 11.35 & 33.56 \\
\hline 567.67 & 6.2 & 4.35 & 1093.33 & 9.59 & 20.33 \\
\hline 105 & 5.32 & 20.85 & 219.44 & 9.61 & 25.14 \\
\hline 272.53 & 11.92 & 52.4 & 592.4 & 19.19 & 80.18 \\
\hline 114.26 & 7.06 & 6.92 & 167.72 & 11.47 & 25.76 \\
\hline 60.61 & 5.44 & 27.82 & 97.06 & 8.49 & 42.11 \\
\hline 59.75 & 13.07 & 35.32 & 133.09 & 18.07 & 91.36 \\
\hline 69.62 & 4.62 & 16.22 & 134.23 & 8.18 & 32.2 \\
\hline
\end{tabular}

$\mathrm{C} / \mathrm{C}$ ratio obtained using the FPIA method with extraction and RIA method without extraction

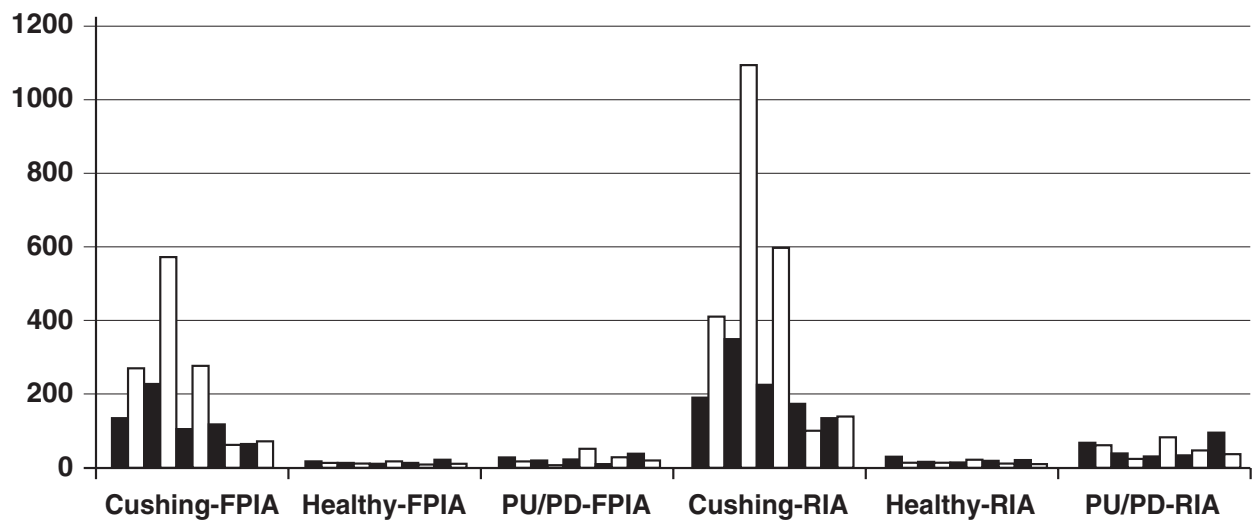

Comparison of individual canine groups

The UCCR values in the three groups of dogs measured using the FPIA with urine extraction and RIA without urine extraction methods were compared. Both methods proved considerable statistical differences between groups. The UCCR in dogs with the Cushing's syndrome was higher $(p<0.01)$ than in healthy dogs and dogs with PU/PD due to other diseases. There were also differences $(p<0.05)$ between healthy dogs and dogs with PU/PD due to other diseases.

Using the FPIA method with urine extraction for the cortisol measurement, the median of the UCCR in dogs with the Cushing's syndrome, healthy dogs and dogs with PU/PD due to other diseases amounted to $125.99 \times 10^{-6}, 6.63 \times 10^{-6}$, and $18.53 \times 10^{-6}$, respectively.

Measuring the urine cortisol by the RIA without urine extraction method, the median of the UCCR in dogs with the Cushing's syndrome, dogs and dogs with PU/PD due to other diseases amounted to $201.99 \times 10^{-6}, 10.48 \times 10^{-6}$, and $37.83 \times 10^{-6}$, respectively. 
Table 2 and Fig. 2

CORTISOL measurement

\begin{tabular}{|c|c|c|c|c|c|}
\hline \multicolumn{3}{|c|}{ FPIA method with urine extraction } & \multicolumn{3}{c|}{ RIA method without urine extraction } \\
\hline Cushing-FPIA & Healthy-FPIA & PU/PD-FPIA & Cushing-RIA & Healthy-RIA & PU/PD-RIA \\
\hline 151.5 & 105.5 & 62.85 & 203 & 188 & 189.5 \\
\hline 185.5 & 80 & 40 & 285.5 & 127.5 & 296 \\
\hline 556.5 & 91.5 & 57.15 & 865 & 142.5 & 149 \\
\hline 425.75 & 143 & 20 & 820 & 221 & 93.5 \\
\hline 189 & 82.5 & 77.15 & 395 & 149 & 93 \\
\hline 1989.5 & 102.5 & 88.55 & 4324.5 & 165 & 135.5 \\
\hline 777 & 77 & 68.6 & 1140.5 & 125 & 255.5 \\
\hline 494 & 106 & 79.3 & 791 & 165.5 & 120 \\
\hline 242 & 91.5 & 143.05 & 539 & 126.5 & 370 \\
\hline 271.5 & 105.5 & 47.85 & 523.5 & 187 & 95 \\
\hline
\end{tabular}

Cortisol measurement using the FPIA with urine extraction and RIA without extraction methods

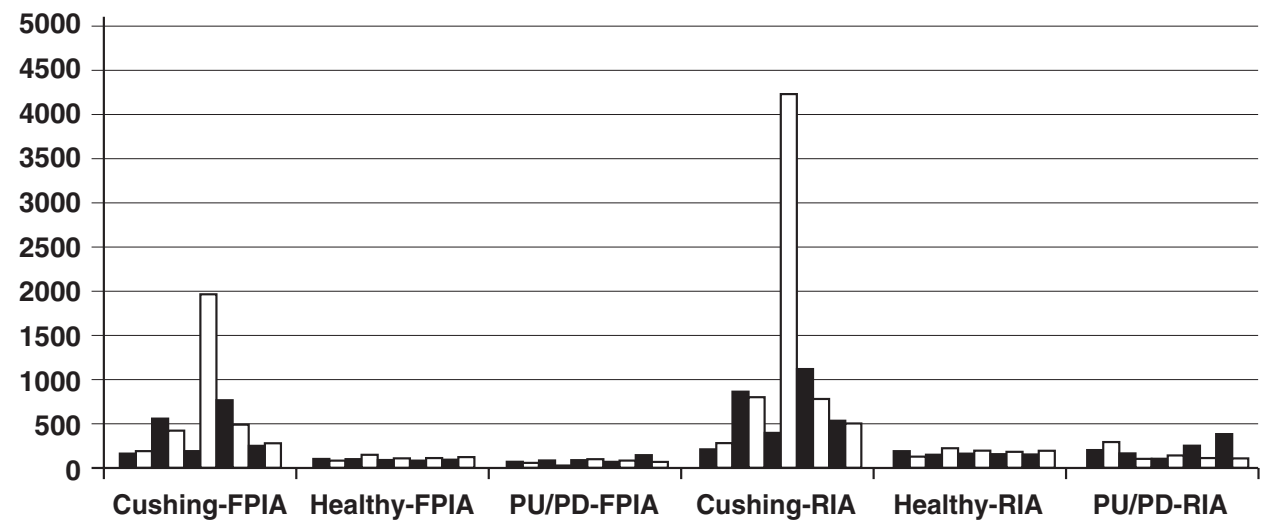

Differences in creatinine values in individual groups

The Kruskal-Wallis test was employed for the purpose of comparing the differences in measured values of creatinine in normal healthy dogs, dogs with hyperadrenocorticism and dogs with PU/PD due to other diseases. The Neményi test of multiple comparisons proved that the creatinine value in healthy dogs (the median of $13.05 \mathrm{mmol} / \mathrm{l})$ is higher $(p<0.01)$ than in dogs with the Cushing's disease (the median of $3.2 \mathrm{mmol} / \mathrm{l}$ ) and dogs with PU/PD due to other diseases (the median of $3.875 \mathrm{mmol} / \mathrm{l}$ ). There were no statistical differences between dogs with the Cushing's syndrome and dogs with PU/PD due to other diseases.

\section{Discussion}

The immunoreactive cortisol concentration in urine is a highly sensitive indicator of hyperadrenocorticism (Stolp et al. 1983). The diagnosis of this disease in human medicine is based on immunoreactive cortisol concentration measurement in a 24-hour urine sample. This method is very easy and precise (Kreeze et al. 1984).

It is not possible to use this method because of practical reasons in veterinary medicine. Therefore Rijnberk et al. (1988) proposed a method which relates the urine cortisol concentration to the creatinine concentration. It is the ratio of cortisol/creatinine that 
considers the changes in the urine specific gravity (Jones et al. 1990). It is then possible to distinguish healthy dogs from dogs with hyperadrenocorticism on the basis of the UCCR. The test may be also performed together with the high-dose dexamethasone suppression test for the purpose of distinguishing the central and peripheral forms of the disease (Galac et al 1997). The conclusive evidence of the test is questioned by some authors (Feldman 1992; Smiley and Peterson 1993; Kaplan et al. 1995) claiming that in patients with PU/PD due to other diseases, like in dogs with hyperadrenocorticism, the UCCR is also increased. The most marked changes in the UCCR are mentioned in patients with diabetes mellitus.

According to the criteria mentioned by Rijnberk et al (1988) the UCCR in healthy dogs is under $10 \times 10^{-6}$ whereas in dogs with hyperadrenocorticism it should be over $10 \times 10^{-6}$. Performing the test together with the high-dose dexamethasone suppression test, the cortisol concentration is suppressed by more than $50 \%$ in relation to the basal concentration in animals with central hyperadrenocorticism. There is no suppression in animals with peripheral hyperadrenocorticism.

The urine cortisol is most frequently measured using the RIA method; the other method (i.e., FPIA) may also be used. Both methods may be performed with or without urine extraction. Urine extraction makes the measurement considerably more valid, because it removes substances interfering with immunologic determinants of the free cortisol.

The aim of our study was to compare two possible methods for the immunoreactive cortisol concentration measurement: FPIA with urine extraction and RIA without urine extraction. Comparing 30 paired urine cortisol values and 30 paired UCCR values in urine, significant differences $(p<0.01)$ were found between the two methods.

In all the animals showing clinical and laboratory signs of hyperadrenocorticism, in accordance with the diagnostic criteria published by Rijnberk, we proved increased UCCR values in urine. All patients with hyperadrenocorticism were further divided with regard to the central and peripheral forms of the disease. These results, however, are not discussed in this paper, because the sensitivity to suppression was not the main aim of the study. The need to distinguish between individual forms of the disease was only based on therapeutic objectives.

In the group of animals with other diseases presented with PU/PD, like other cited authors (Feldman 1992; Smiley and Peterson 1993; Kaplan et al. 1995), we found increased UCCR values. This group of patients presented with PU/PD contained mainly patients with diabetes mellitus ( 8 individuals), because there are described most marked changes in the $\mathrm{C} / \mathrm{C}$ ratio.

Unfortunately, it was not possible to compare results obtained using the RIA method without and with urine extraction, because only the RIA method without urine extraction is used in the Czech Republic. It is much simpler and of sufficient sensitivity for the need of human medicine where the immunoreactive cortisol concentration measurement in a $24-$ hour urine sample is made.

It may be concluded that the UCCR measurement may be used as a sensitive diagnostic method for hyperadrenocorticism in dogs. In patients with polyuria and polydipsia due to other diseases, there are also increased values of the UCCR, the specific diagnosis, however, may be achieved using other methods. Both methods of immunoreactive cortisol determination in urine (i. e., FPIA with urine extraction and RIA without urine extraction) can be used for clinical diagnosis of hyperadrenocorticism, however, the above mentioned differences should be considered.

\section{Stanovení imunoreaktivního kortizolu v moči psů a jeho validita při diagnostice hyperadrenokorticizmu}

Cílem práce bylo porovnání dvou metod stanovení imunoreaktivního kortizolu a posouzení validity poměru kortizol/kreatinin v moči psů. U tří skupin psủ (1) zdravých, (2) 
s hyperadrenokorticizmem, (3) s jinými onemocněními prezentujícími se polyurií a polydipsií (PU/PD) byl stanovován poměr kortizol/kreatinin $(\mathrm{C} / \mathrm{C}) \mathrm{v}$ moči. Všechna stanovení kortizolu v moči byla prováděna zároveň dvěma metodami: (1) fluorescenční polarizační imunoanalýzou (FPIA) s extrakcí moči, (2) radioimunoanalytickou metodou (RIA) bez extrakce moči. Výsledky 30 párových stanovení kortizolu a 30 párových hodnot poměru C/C byly mezi sebou porovnány. $\mathrm{K}$ vyhodnocení byl užit Wilcoxonův test. Ukázalo se, že rozdíly mezi metodami FPIA s extrakcí a RIA bez extrakce jsou statisticky vysoce významné $(p<0,01)$. Zatímco při stanovení volného kortizolu v moči metodou FPIA $\mathrm{s}$ extrakcí moči byl medián poměru $\mathrm{C} / \mathrm{C} 18,53 \times 10^{-6}$, u metody RIA bez extrakce moči byl $37,83 \times 10^{-6}$. Dále byly porovnávány hodnoty poměru $\mathrm{C} / \mathrm{C}$ u jednotlivých skupin mezi sebou. Poměr C/C u psů s Cushingovým syndromem byl statisticky vysoce významně vyšší $(p<0,01)$ než u psů zdravých a u psů s PU/PD. Statisticky vysoce významné rozdíly $(p<0,05)$ byly zaznamenány i mezi poměrem $\mathrm{C} / \mathrm{C}$ u psů zdravých a u psů s $\mathrm{PU} / \mathrm{PD}$. Obě uvedené metody stanovení imunoreaktivního kortizolu $\mathrm{v}$ moči jsou v klinické diagnostice hyperadrenokorticizmu u psa využitelné, výše uvedené diference je však třeba vzít v úvahu.

Acknowledgements

We are grateful to Ing. Hájek, Dr. Malášková for his valuable comments on the methods and to Professor Hořín, Dr. Matoušková, and Dr. Vrbas for the statistical evaluation.

This study was enabled by the research intention of the Ministry of Education, Youth and Sports of the Czech Republic No 161700002.

\section{References}

FELDMAN, E. C. 1983: Distinguishing dogs with functioning adrenocortical tumors from dogs with pituitary dependent hyperadrenocorticism. J. Am. Vet. Med. Assoc. 183: 195-200

FELDMAN, E. C. 1996: Hyperadrenocorticism. In: FELDMAN, E. C., NELSON, R. W: Canine and feline endocrinology and reproduction. W. B. Saunders Comp., Philadelphia, pp. 187-261

FELDMAN, E. C., FELDMAN, M. S. 1996: Use of low-and high-dose dexamethasone tests for distinguishing pituitary-dependent from adrenal tumor hyperadrenocorticism in dogs. J. Am. Vet. Med. Assoc. 209: 772-775

FELDMAN, E. C., MACK, R. E. 1992: Urine cortisol:creatinine ratio as a screeening test for hyperadrenocorticism in dogs. J. Am. Vet. Med. Assoc. 200: 1637-1641

GALAC, S., KOOISTRA, H. S., TESKE, E., RIJNBERK, A. 1997: Urinary corticoid/creatinine ratio in the differentiation between pituitary-dependent hyperadrenocorticism and hyperadrenocorticism due to adrenocortical tumour in the dog. Vet. Quart. 19: 17-20

JONES, C. A., REFSAL, K. R., LIPPERT, A. C., NACHREINER, R. F., SCHWACHA, M. M. 1990: Changes in adrenal secretion as reflected in the urinary cortisol/creatinine ratio in dogs. Domest. Anim. Endocrinol. 7: $559-572$

KAPLAN, A. J., PETERSON, M. E., KEMPPAINEN, R. J. 1995: Effects of disease on the results of diagnostic tests for use in detecting hyperadrenocorticism in dogs. J. Am. Vet. Med. Assoc. 207: 445-451

KEMPPAINEN, R. J., LORENZ, M. D., THOMPSON, F. N. 1982: Adrenocortical suppression in the dog given a single intramuscular dose of prednisone or triamcinolone acetonide. Am. J. Vet. Res. 42: 204-206

KEMPPAINEN, R. J., PETERSON, M. E. 1994: Animal models of Cushing's disease. Trends Endocrinol. Metab. 5: $21-28$

KREEZE, A., VELEMÍNSKY, J., PUTZ,Z. 1984: Vol'ný močový kortizol v diagnostike Cushingovho syndrómu. Čas. Lék. Čes. 123: 1536-1540

McNICOL, A. M., THOMSON, H., STEWART, C. J. R. 1983: The corticotrophic cells of the canine pituitary gland in pituitary-dependent hyperadrenocorticism. J. Endocrinol. 96: 303-308

MEIJER, J.C., BRUIJNE, J., RIJNBERK, A., CROUGHS, R. J. M. 1978: Biochemical characterization of pituitary-dependent hyperadrenocorticism in the dog. J. Endorinol. 77: 111-118

MILLER, J., CRAPO, L. 1994: The biochemical diagnosis of hypercortisolism. The Endocrinologist 4: 7-15

MOORE, G. E., MAHAFFEY, E, A., HOENIG, M. 1992: Hematologic and serum biochemical effects of longterm administration of anti-inflammatory doses of prednisone in dogs. Am. J. Vet. Res. 53: 1033-1037

MORIELLO, K. A., FEHRER-SAWYER, S. L., MEYER, D. J. et al 1988: Adrenocortical suppression associated with topical otic administration of glucocorticoids in dogs. J. Am. Vet. Med. Assoc. 193: 329-331

NORMAN, E. J., THOMPSON, H., MOONEY, C. T. 1999: Dynamic adrenal function testing in eight dogs with hyperadrenocorticism associated with adrenocortical neoplasia. Vet. Rec. 144: 551-554

ORTH, D.N. 1995: Cushing's syndrome. N. Engl. J. Med. 332: 791-803

PETERSON, M. E. 1984: Hyperadrenocorticism. Vet. Clin. North Am. Small Anim. Pract. 14: 731-749 
REUSCH, C. E., FELDMAN, E. C. 1991: Canine hyperadrenocorticism due to adrenocortical neoplasia. J. Vet. Int. Med. 5: $3-10$

RIJNBERK, A. 1996: Adrenals. In: RIJNBERK, A (ed.): Clinical endocrinology of dogs and cats. Kluwer Academic Publishers, Dordrecht, pp. 61-93

RIJNBERK, A., WEES, A., MOL, J. A. 1988: Assessment of two tests for the diagnosis of canine hypeadrenocorticism. Vet. Rec. 122: 178-180

SMILEY, L. E., PETERSON, M. E. 1993: Evaluation of a urine cortisol:creatinine ratio as a screening test for hypeadrenocorticism in dogs. J. Vet. In. Med. 7: 163-168

STOLP, R., RIJNBERK, A., MEIJER, J. C. 1983: Urinary corticoids in the diagnosis of canine hyperadrenocorticism. Research in Veterinary Science 34: 141-144

SVOBODA, M., DOUBEK, J., KOLEVSKÁ, J., ČADA, F. 1998: Hyperadrenokorticizmus. In: SVOBODA, J., DOUBEK, J. (eds.) Endokrinologie psa a kočky. ČAVLMZ Brno, pp. 112-130 